\title{
The Origins of the \\ Iowa Development Commission: Agricultural Transformation and Industrial Development in Mid-Twentieth-Century Iowa
}

\author{
KeITH OREJEL
}

ON JULY 1, 1945, the Fifty-first Iowa General Assembly passed an act creating the Iowa Development Commission (IDC). The commission, as a later report explained, was to serve as the "state's official promotional agency," tasked with overseeing postwar economic development. The state legislature assigned the IDC a "three-fold responsibility": (1) research, specifically the "collection of facts and figures pertinent to Iowa's economy"; (2) information, centering on a "program of publicity and education about Iowa"; and (3) promotion, defined as "the procurement of new industrial enterprise, and the encouragement of existing business and industry." The IDC's membership was composed largely of "business and professional men," along with a handful of state legislators, all of whom were appointed by the governor. A professional staff headed by a salaried director oversaw the group's day-to-day operations. ${ }^{1}$

Although it received only modest attention at the time, the creation of the Iowa Development Commission was a groundbreaking event. The IDC was the first of its kind within the state-

1. "Report of Activities of the Iowa Development Commission," 1, 24, folder: Misc. 1952, box 1, Economic Development Collection: Commission Minutes and Related Materials, 1940-1954, State Historical Society of Iowa, Des Moines (SHSI-DM).

THE ANNALS OF IOWA 76 (Winter 2017). (C) The State Historical Society of Iowa, 2017. 
a permanent government agency dedicated primarily to promoting industrialization. ${ }^{2}$ With the formation of the IDC, the state of Iowa entered a modern era of government-sponsored economic development, as the public sector played an expansive role in the pursuit of manufacturing and other enterprises. A bold move into the cutthroat competition for new industry, the creation of the IDC represented a direct response to long-term agricultural transformations and new industrial opportunities that converged during World War II.

Since the 1920s, farmers throughout rural America had confronted a volatile global market, with declining crop prices resulting in shrinking incomes and rising farm foreclosure rates. In an attempt to hold on to their property and maintain their standards of living, many farmers adopted new practices aimed at increasing productivity. Farmers with available capital invested in machinery (primarily tractors) and other technological innovations to maximize output. But these decisions not only failed to alleviate the plight of the farmer, they also initiated structural transformations that undermined the fabric of rural society. Increased output drove prices down further, necessitating ever greater production to survive. The social implications of these developments were staggering. As rural historian David Danbom has shown, "The minority of farmers whose ownership of tractors increased productivity intensified economic pressures on others." Many farmers mortgaged their property to the hilt in order to keep up, while those unable to compete "withdrew from agriculture, usually by selling to expanding neighbors." With "fewer farms and declining labor needs on those that remained," the "pace of rural-to-urban migration" reached new heights. Outmigration led to the "deterioration of rural social networks," since "depopulation" resulted in "fewer parishioners for churches and fewer pupils for schools." Local businesses and other institutions also buckled under the weight of mass exodus. ${ }^{3}$

2. An examination of state institutions listed in the Iowa Official Register for the years 1882, 1886, 1890, 1894, 1898, 1902, 1906, 1909/1910, 1915/1916, 1921/1922, $1927 / 1928,1933 / 1934$, and 1939/1940 suggests that no comparable organization existed in Iowa prior to World War II.

3. My main source for this broad sketch is David B. Danbom's wonderfully synthetic survey, Born in the Country: A History of Rural America, 2nd ed. (Baltimore, 
Despite attempts by federal bureaucrats to limit overproduction during the 1930s, the New Deal did not significantly hinder the transformation of agriculture. In some ways, the New Deal propelled farm modernization. Federal agencies such as the Agricultural Adjustment Administration and the Commodity Credit Corporation provided American farmers with infusions of capital through acreage reduction and price support programs. With fewer overall acres in use and more income generated by transfer payments and government-backed price levels, market-oriented farmers continued to improve their individual circumstances through greater productivity. ${ }^{4}$

Farm mechanization and rural outmigration were already issues by the early 1940s, but World War II accelerated those processes. The global conflict catalyzed what some scholars have referred to as a "production revolution." The number of tractors in use exploded during the war in response to labor shortages, resulting in the permanent replacement of manpower with machines. Simultaneously, rural and small-town inhabitants migrated en masse to nearby industrial centers to fill growing demand in wartime factories. ${ }^{5}$

Iowa was hit hard by agricultural restructuring. Farming in Iowa underwent the early stages of consolidation (a process that would continue for much of the century). Larger, more productive farms gobbled up smaller units, pushing many out of agriculture.

2006), 185-205 (quotes on 196-97). The literature on agriculture modernization in the twentieth century is expansive. A few notable studies have especially informed my understanding: Daniel Nelson, Farm and Factory: Workers in the Midwest, 1880-1990 (Bloomington, IN, 1995); Pete Daniel, Breaking the Land: The Transformation of Cotton, Tobacco, and Rice Cultures Since 1880 (Urbana, IL, 1985); Jack Temple Kirby, Rural Worlds Lost: The American South, 1920-1960 (Baton Rouge, LA, 1987); and Carolyn Dimitri, Anne Effland, and Neilson Conklin, "The Twentieth Century Transformation of U.S. Agriculture and Farm Policy," Economic Information Bulletin No. 3, June 2005, Economic Research Service, U.S. Department of Agriculture.

4. Danbom, Born in the Country, 206-33. The historian Sarah Phillips has argued that New Deal farm policymakers were divided "between those who believed that farmers had to 'get big or get out' and those who claimed that more could be done to help farmers remain on their land." Over time, federal policy "shifted toward those who believed that there were just too many farmers." This Land, This Nation: Conservation, Rural America, and the New Deal (New York, 2007), 9-11.

5. Danbom, Born in the Country, 233-39. 
Between 1920 and 1950, Iowa's farm population declined from 984,799 to 790,424 . Outmigration and depopulation caused the state as a whole to experience anemic population growth in the 1920s, 1930s, and 1940s, with increases of only 2.8, 2.7, and 3.3 percent. The U.S. population, in comparison, grew by 16.1, 7.2, and 14.5 percent during the same decades. ${ }^{6}$

During World War II, these decades-old rural ailments intersected with new industrial opportunities. In response to the outbreak of war in Europe, the state legislature in 1940 created the Iowa Industrial and Defense Commission, which brought together a coalition of elected officials, agribusiness representatives, labor leaders, industrialists, and other notables. The commission melded state-level civilian defense with a campaign to acquire wartime industries. The acquisition of several major ordnance plants and smaller factories during the war created enthusiasm for industrial development. Proud of their accomplishments, but fearful of the potentially disastrous effects of peacetime reconversion, state officials called for a permanent program of industrialization after the conflict.

The Iowa Development Commission (IDC) was created in 1945 out of the simultaneous confidence created by the war that new industry would come to Iowa and growing fears about the continual loss of farm jobs and rural inhabitants. In Iowa, industrial development and agricultural transformations went hand in hand. But if changes in farming motivated many state officials to pursue industrialization, agricultural interests shaped the nature of Iowa's postwar industrial campaign. Agribusiness representatives, primarily the Iowa Farm Bureau Federation, insisted that new industries should not infringe on large landholders' access to cheap labor. Also, agricultural interests pressed for industries

6. Leon Edgar Truesdell, Farm Population: 1880 to 1950 (Washington, DC, 1960), table 14, p. 21, for 1920; table 20, p. 27, for 1950. Population data taken from Iowa Data Center Publication, "Total Population in Iowa Counties, 1850-2010," www.iowadatacenter.org/archive/2011/02/countytotalpop.pdf. For U.S. population data, see Frank Hobbs and Nicole Stoops, U.S. Census Bureau 2000 Special Reports, Series CENSR-4, Demographic Trends in the 20th Century (Washington, DC, 2002), 13, at www.census.gov/prod/2002pubs/censr-4.pdf. For agricultural changes in Iowa, see Mark Friedberger, "The Modernization of Iowa's Agricultural Structure in the Twentieth Century," in Iowa History Reader, ed. Marvin Bergman, 2nd ed. (Iowa City, 2008), esp. 378-84. 
that would process farm products, thereby generating demand for their crops, eggs, milk, and meat.

The IDC addressed these various interests by laying out its vision for a "balanced economy." In early promotional material, the IDC melded agricultural transformations and industrial development into a blueprint that promised prosperity, harmony, and growth. In this synthesis, displaced agricultural producers and laborers, freed from farming by mechanization and scientific advancements, would staff newly acquired industries. Promising mutual benefit to both agriculture and industry, the IDC gave the most attention to recruiting enterprises that would utilize the state's natural resources and farm products. Those business concerns would then increase demand for Iowa's abundant raw materials.

By analyzing the origins of the IDC, this article adds to the wealth of scholarship highlighting the interconnection between agriculture and industry in the greater Midwest. In his classic work, Nature's Metropolis, William Cronon emphasized the symbiotic relationship between city and countryside, showing how agricultural production, resource extraction, and rural consumerism in the hinterland facilitated the rise of urban industrial Chicago. ${ }^{7}$ More recent scholarship, most notably the valuable work of Wilson J. Warren, has emphasized the persistent importance of "agro-industrialization" in the economic development of Iowa and the Midwest. Farm-oriented industries, such as meatpacking and flour milling, have, since the nineteenth century, been at the center of the rural industrial economy. ${ }^{8}$ The early years of the

7. William Cronon, Nature's Metropolis: Chicago and the Great West (New York, 1992). 8. For the most comprehensive survey of "agro-industrialization" in the Midwest, see Wilson J. Warren, "Beyond the Rust Belt: The Neglected History of the Rural Midwest's Industrialization after World War II," in The Rural Midwest Since World War II, ed. J. L. Anderson (DeKalb, IL, 2014), 72-102. There are numerous studies on meatpacking, food processing, and other agro-industrial enterprises. To cite just a small portion of this literature: Deborah Fink, Cutting into the Meatpacking Line: Workers and Change in the Rural Midwest (Chapel Hill, NC, 1998); Nelson, Farm and Factory; Donald Stull, Michael J. Broadway, and David Griffith, eds., Any Way You Cut It: Meat Processing and Small-Town America (Lawrence, KS, 1995); Wilson J. Warren, Struggling with 'Iowa's Pride': Labor Relations, Unionism, and Politics in the Rural Midwest Since 1877 (Iowa City, 2000); idem, Tied to the Great Packing Machine: The Midwest and Meatpacking (Iowa City, 2007); 
Iowa Development Commission represented one facet of these longstanding and well-documented development patterns.

At the same time, the IDC represented an important institutional breakthrough in the history of rural industrialization, a development that has received little scholarly attention. The creation of the IDC signaled the state government's modern stewardship of economic development, elevating industrialization to official public policy. Much like James C. Cobb's characterization of Mississippi's Balance Agriculture with Industry program, the IDC embodied a "long-term commitment to state sanctioned and supervised economic development." 9 This article contributes to existing scholarship by showing how and why industrial development became institutionalized in Iowa. Industrialization achieved a new level of government sponsorship during World War II because of concerns about rapid changes in agriculture. The precipitous decline in farm jobs led many state officials to conclude that only concerted government action could stem outmigration. Faith in state intervention was reinforced by Iowa's wartime experiment with industrial development. Iowa had experienced industrialization in the past, but it was the agrarian crisis of the mid-twentieth century that produced the modern form of government-directed development exemplified by the IDC.

It is important to note that this article, as the title indicates, is an origin story. The IDC would have a long career, operating under its original name until 1986, when it was replaced by the Department of Economic Development (which was later supplanted by the Iowa Economic Development Authority). Rather than tackling the organization's entire history, this study examines the IDC's founding and early promotional efforts, focusing especially on the interconnection between agriculture and industrial development.

George May, "Recent Industrial Development" and "Iowa Industries," Palimpsest 37 (1956), 229-88; L. O. Cheever, "Comments on 11 Years" and "Iowa Industries," Palimpsest 48 (1967), 93-118; L. O. Cheever, "Industries of Iowa-II," and "Iowa Industries," Palimpsest 49 (1968), 1-40.

9. James C. Cobb, The Selling of the South: The Southern Crusade for Industrial Development, 1936-1980 (Baton Rouge, LA, 1982), 33. 
THE IOWA Industrial Resources and Defense Council held its first meeting in the offices of Governor George A. Wilson at two o'clock on Tuesday, September 10, 1940, almost a year after the invasion of Poland by German forces, and roughly four months since the fall of France. ${ }^{10}$ Present at the meeting were representatives from the most important interest groups in the state, including A. A. Couch, president of the Iowa Federation of Labor; Frank Wilson, president of the Iowa United Mine Workers of America; Allen Klein, vice-chairman of the Iowa Farm Bureau; R. R. O'Brien, publisher of the Council Bluffs Nonpareil; George S. Call, a member of the executive committee of the Midwest Defense Conference; J. Tracy Garrett, editor of the Burlington Hawkeye-Gazette; Ralph Smith, president of the Iowa Grange; Edward Kimball, president of the Iowa Manufacturers Association (a state branch of the National Association of Manufacturers); L. A. Rowland, vice-president of John Deere and Company; and Dale L. Maffitt, general manager of the Des Moines Water Works. The group's diversity reflected the need for economic cooperation among all sectors of the Iowa economy, as well as for communication between public representatives and private interest groups, for the purpose of wartime preparedness. In the words of one member, the "cross-section of representation on the Council" was an attempt at "unselfishness and working toward the welfare of both the state and the nation." 11

Governor Wilson started the gathering by laying out the goals and responsibilities of the newly formed group. Given recent developments across the globe, the central focus was Iowa's role "in the national defense program." Wilson called for the collection of data on "Iowa's manufacturing, processes, transportation, resources and labor," all of which was meant to ensure that the state

10. Both events had a tremendous effect on American public opinion and produced increased calls for U.S. military preparedness. George C. Herring, From Colony to Superpower: U.S. Foreign Relations Since 1776 (New York, 2008), 519, 537.

11. "Minutes of the Meeting of the Iowa Industrial Resources and Defense Council, September 10, 1940," 1, folder: 1940, 1941, box 1, Economic Development Collection: Commission Minutes and Related Materials, 1940-1954, SHSI-DM. For a general timeline on World War II military developments, see David Kennedy, Freedom from Fear: The American People in Depression and War, 1929-1945 (New York, 2005). 
would be ready at a moment's notice should the country start mobilizing for war. Undergirding these grand ideals and national civic values, however, were more material and pragmatic concerns. Wilson insisted that all "the information received by the Council" must be "made available to every community in Iowa" so that "the industries and citizens of the state may receive the fullest benefit of this national expansion" of the defense sector. Wilson made clear that one of the commission's central duties was "making ... applications for the location of new industries" in Iowa. ${ }^{12}$

Hovering over these initiatives were the menacing specters of outmigration and depopulation that had plagued Iowa since the 1920s. Commission member L. A. Rowland, vice-president of John Deere and Company, "expressed the opinion that labor supply was basic and that everything must be done to keep labor here in Iowa." Noting that the "construction of munitions factories has a tendency to draw not alone men but supplies from Iowa for the industrial centers," Rowland implicitly suggested that an agricultural state like Iowa could only hope to hold on to its domestic population and economic resources by achieving some degree of industrialization. ${ }^{13}$ Many in Iowa's local communities shared Rowland's perspective. The Centerville Iowegian, the town of Centerville's local newspaper, argued in 1940 that "southern Iowa has many ex-farmers and coal miners who are now jobless. They must either remain in the small towns on relief or go to the cities to get work." 14

Council members realized that the imperatives of modern warfare played to their advantage. Observers of the international scene forecasted that total war, especially the aerial bombardments witnessed during the Spanish Civil War and the invasion of Poland, made the concentration of industrial facilities in large urban centers a defensive liability. ${ }^{15}$ As a result, Frank Wilson of

12. "Minutes of the Meeting of the IIRDC, September 10, 1940," 2.

13. Ibid., 3.

14. “Iowa Industrial Institute Seeks War Industries," Centerville Iowegian, 12/19/ 1940.

15. George C. Herring, From Colony to Superpower: U.S. Foreign Relations Since 1776 (New York, 2008), 484. An excellent discussion of aerial warfare's psychological effects and its political ramifications for the larger world can be found in Richard Evans, The Third Reich in Power (New York, 2005), and idem, The Third Reich at War (New York, 2009). 
the Iowa United Mine Workers of America asserted, "We were undoubtedly headed toward the decentralization of industry," which would "apparently be accomplished by the necessity of national defense." Governor Wilson made similar claims in numerous public statements, arguing on one occasion, "If there is any single lesson which has come out of Europe, it is that the decentralization of defense industry is equal in importance to the scattering of airports." 16

From the Defense Council's first meeting it was apparent that Iowa's industrial development program would have to accommodate itself to the demands of agribusiness. Allen Klein, vicechairman of the Farm Bureau, insisted that all "new plants will require" a "proper relation to agriculture." Klein spoke for Iowa's "agricultural interests" when he argued that "consideration" in "locating industries" had to be given to ensure that there would be "no shortage or surplus of labor." While Klein claimed to have the interests of rural and small-town communities at heart, he was obviously attempting to protect agribusiness's access to cheap labor when he concluded, "Larger industries must be located near larger communities." 17

The first meeting of the Iowa Industrial Resources and Defense Council, which would soon be renamed the Iowa Industrial and Defense Commission (IIDC), set the tone for the organization's wartime operations. The IIDC would play a dual role. On the one hand, it would ensure military preparedness and domestic defense by coordinating with representatives from agriculture, industry, and labor. Simultaneously, it would attempt to bring defense, munitions, and ordnance plants to the state. Policymakers rationalized and justified these measures by arguing that Iowa would lose inhabitants to urban centers outside the state if it did not acquire manufacturing enterprises of its own. Implicit within this argument was a growing concern that Iowa was too dependent on farm jobs, which not only paid less than their industrial counterparts but also were in shrinking supply as a result of mechanization. By war's end, this implicit logic would become

16. "Minutes of the IIRDC, September 10, 1940," 3; “Wilson Says Iowa Suited for Some Defense Industry," Centerville Iowegian, 8/27/1940.

17. "Minutes of the IIRDC, September 10, 1940," 4. 
an explicit argument as the need to replace agricultural employment with industrial jobs would be the central rationale for the creation of the Iowa Development Commission.

Between 1940 and 1945, the IIDC aggressively campaigned to attain defense contracts. In March 1941 the commission passed a motion calling for Governor Wilson to travel to Washington, D.C., to "confer with the Iowa senators and the Iowa congressional delegation on the problem of obtaining industries for Iowa." In July of that same year the commission decided to acquire new office space and hire more employees to establish "a branch office of the Defense Contract Service Division of the Office Production Management," an attempt to solicit federal contracts. These initiatives had significant success, as defense spending in Iowa skyrocketed, rising to $\$ 57$ million by March 1941 and then to $\$ 68$ million the following month. ${ }^{18}$

What exactly did the IIDC do to bring new industry to Iowa? Primarily, members of the IIDC worked closely with communities that wanted to secure defense-related industries. The IIDC's most important function was facilitating interaction among local towns, Iowa's congressmen, and wartime government agencies. The attempt to secure a corn alcohol plant for the small town of Eagle Grove provides a compelling example of how the IIDC navigated various political channels in pursuit of wartime industries. On March 4, 1941, a "delegation of business men" from Eagle Grove met with the IIDC to "discuss the possibilities of corn alcohol [plant] construction in northern Iowa." On March 13, IIDC Secretary Rodney Q. Selby met with the director of the Agricultural Experiment Station at Iowa State College "to ask him to prepare material" on the manufacture of corn alcohol that "could be presented to defense production agencies in Washington." About a week later, Selby visited Washington, D.C., to meet with Senator Guy M. Gillette (D-IA) to explain how these plants could produce corn alcohol necessary for the production of explosives. Gillette also proposed the possibility that corn alcohol could be

18. "Minutes of the Meeting of the Iowa Industrial and Defense Commission, March 26, 1941," folder: 1940, 1941, box 1, Economic Development Collection: Commission Minutes and Related Materials, 1940-1954, SHSI-DM; "Minutes of the Meeting of the Iowa Industrial and Defense Commission, July 23, 1941," ibid.; Lisa L. Ossian, The Home Fronts of Iowa, 1939-1945 (Columbia, MO, 2009), 51. 
used as a motor fuel. After receiving the report produced by agricultural experts at Iowa State, Senator Gillette promised to discuss the finding with the secretary of war. Selby also disseminated the material to Iowa Democratic Senator Clyde Herring and "other members of Iowa's delegation in Congress." 19

Although the War Department recognized the importance of ethyl alcohol for military purposes, notably in the production of smokeless powder, it informed Senator Gillette and the IIDC that the "present facilities will be adequate to supply . . . military needs." Nonetheless, the IIDC pounced on its newfound access to federal wartime bureaucracies. In A pril 1941 IIDC Secretary Selby met with P. H. Groggins, a chemical consultant who worked with the Council of National Defense, to once again promote the construction of corn alcohol plants in Iowa. Groggins reaffirmed the War Department's initial assessment, informing the IIDC official that there was little demand for industrial corn-based alcohol. ${ }^{20}$

This did not deter Iowa's public officials, however. On May 20, 1941, Governor George Wilson, IIDC Chair Edward Kimball, and Secretary Selby met with Under Secretary of War Robert Patterson and two officials from the Office of Production Management to once again press for the "construction of corn alcohol plants in Iowa as a needed war production measure." In January 1942, the IIDC held a meeting in Ames, to discuss how corn alcohol could be used "as an adjunct to synthetic rubber manufacture." Throughout February and March 1942, IIDC officials continued to travel to Washington to champion corn alcohol as a viable ingredient for the manufacture of synthetic rubber and explosive devices. ${ }^{21}$

In March 1942 the entire process came full circle when Otto Knudsen, a local businessman from Eagle Grove, joined Selby and several IIDC members on a trip to Washington, D.C. The group met with Senator Gillette, numerous Iowa representatives, and Vice-President Henry A. Wallace to once again push for the construction of corn alcohol factories in Iowa. At one point, Dean

19. Untitled report, Iowa Industrial and Defense Commission, July 15, 1942, 1, folder: 1943, box 1, Economic Development Collection: Commission Minutes and Related Materials, 1940-1954, SHSI-DM.

20. Ibid.

21. Ibid., $2-3$. 
Buchanan, director of Iowa State College's Agricultural Experiment Station, was called to testify before a U.S. Senate subcommittee on the prospect of corn alcohol production within the state. The campaign remained active throughout the summer of 1942, with IIDC member A. A. Couch lobbying in "Washington ... to forward the promotion of corn alcohol plant construction." In the latter months of 1942, Iowa's spokespersons focused their sales pitch on the use of grain alcohol in the production of synthetic rubber. Within Congress, Iowa's elected officials, most notably Senator Gillette, pushed hard to convince their colleagues that grain alcohol could replace the then dominant petroleum in the manufacture of synthetic rubber. ${ }^{22}$

Despite early setbacks, the IIDC's campaign was an eventual success, as Iowa received numerous military contracts to manufacture alcohol from corn and other grain products. In early 1943 the federal government initiated an ambitious program to spur the production of grain alcohol, which resulted in the construction of several industrial plants in Iowa. In February 1943 the Grain Processing Corporation of Muscatine, signed a contract with the federal Defense Plants Corporation to build a factory that would "produce 8,500,000 gallons of alcohol a year" for sale to "the defense supplies corporation" as part of the production of synthetic rubber. The following month, the cities of Dubuque and Keokuk were also picked as sites for federally sponsored grain alcohol plants. Perhaps most heartening for the IIDC was the announcement on March 10, 1943, that Otto Knudsen's Iowa Farm Processing Cooperative was "allocated the contract to construct and operate the Dubuque plant," and that the town of Eagle Grove had also been selected as a site for one of five other future grain alcohol plants. Both measures were fitting since Knudsen and Eagle Grove had been deeply involved in lobbying for wartime grain alcohol production. ${ }^{23}$

22. Ibid., 3-4; "Grain Alcohol-Synthetic Rubber Fight to Senate Floor Today," Centerville Iowegian, 7/20/1943. See also "Gillette in New Inquiry," Centerville Iowegian, 1/5/1943. For the broader history of this campaign, see Mark Finlay, Growing American Rubber: Strategic Plants and the Politics of National Security (New Brunswick, NJ, 2009), esp. ch. 5.

23. "Gillette Predicts Gov't to Expand Alcohol Program," Centerville Iowegian, 3/6/1943; Finlay, Growing American Rubber, 190-97; "Contract for Alcohol Plant Given Muscatine: Facilities to Produce 8,500,000 Gallons a Year," Centerville 
Grain alcohol plants represented just one part of Iowa's wartime industrial boom. Several large-scale munitions and ordnance facilities located in the state, along with a host of smaller defense-related enterprises. One of the earliest and most noteworthy acquisitions was the Iowa Ordnance Plant, located near the city of Burlington. Construction of the massive factory began in January 1941, and the $\$ 60$ million ordnance plant was officially dedicated on July 31, 1941. By the end of the war, the Iowa Ordnance Plant, according to historian Lisa Ossian, would turn out " 25 million mortar shells, 200,000 medium-caliber shells, 5 million major-caliber shells, and 2.5 million bombs." The Iowa Ordnance Plant was soon followed by the Des Moines Ordnance Plant, an equally impressive munitions factory located in the suburban community of Ankeny. Along with these behemoth acquisitions, a slew of private businesses converted their plants for wartime production. In southern Iowa, the Hercules Manufacturing Plant, located in the town of Centerville, refitted its operations and by 1943 was "wholly in the production of defense materials," including the manufacturing of "steel casing and machining" as well as "stump pullers." 24

Along with its promotional duties, the IIDC also played a central role in helping local communities adjust to rapid industrialization. In May 1941 IIDC Chair Edward Kimball made a personal visit to Burlington's Iowa Ordnance Plant. After inspecting the facilities, he appointed Burlington residents to an advisory committee that would inform the IIDC on "problems" relating to industrialization. The IIDC addressed some of the primary issues related to wartime industrial development, such as pressing for legislation that would help meet the demand for housing in cities and towns that gained defense contracts. ${ }^{25}$

Iowegian, 2/15/1943; "Keokuk to Get Alcohol Plant WPB Announces," and "Plants Expected to Produce at Least 56,000,000 Gallons a Year," Centerville Iowegian, 3/4/1943; "Grain Alcohol Plant," Centerville Iowegian, 3/13/1943; "WPB Gives Contracts to Five Iowa Plants," Centerville Iowegian, 3/10/1943. See also "Feud Develops over Spud Sugar," Centerville Iowegian, 10/6/1945; and "Plant to Produce Enzyme in State," Centerville Iowegian, 5/21/1945.

24. Ossian, Home Fronts of Iowa, 56-57, 62, 63; "Hercules Workers Vote to Delay Proposed Walk Out," Centerville Iowegian, 2/11/1943.

25. "Minutes of the Meeting of the Iowa Industrial and Defense Commission, May 21, 1941," folder: 1940, 1941, box 1, Economic Development Collection: 
World War II generated newfound interest in industrial development as the state successfully acquired defense and munitions plants. To a degree never before witnessed, Iowa's elected officials, small-town business leaders, and various interest groups campaigned to bring industry to their state. Wartime mobilization offered these public and private citizens access to Congress, federal bureaucracies, and even the executive branch. World War II provided firsthand experience in industrial development. The global conflict offered local and state actors a model for industrializing Iowa and a sense of excitement that the state's agricultural economy could be diversified with manufacturing.

WHILE WARTIME INDUSTRY BOOMED in Iowa, the state's farm sector was undergoing dramatic changes with long-term implications. These two processes were directly connected. An abundance of well-paying manufacturing jobs drew farmers and laborers off the land. Farm jobs tended to pay less than manufacturing employment, so thousands of field hands, tenant farmers, and even independent landholders left agriculture in search of industrial employment. Many rural and small-town inhabitants fled their communities for Iowa's booming industrial areas or urban centers elsewhere in the region, such as Detroit or Chicago. As a result, farmers experienced a dire labor shortage. To make up for the lack of available manpower, farmers turned to machines. Farm mechanization greatly expanded during World War II. Sales of tractors and other equipment spiked throughout the conflict. These capital investments then created an autocatalytic effect, whereby a labor shortage resulted in mechanization, which then eliminated agricultural jobs for good. The number of farm laborers decreased significantly during the war. As the conflict continued, it became clear that farming would not produce postwar job growth. ${ }^{26}$

Commission Minutes and Related Materials, 1940-1954, SHSI-DM. “Minutes of the IIDC, March 25, 1941," ibid.

26. Ossian, Home Fronts of Iowa, 39-46; Nelson, Farm and Factory, 140-41, 165; Danbom, Born in the Country, 229-63; Warren, Struggling with 'Iowa's Pride,' esp. 68-84; Warren, Tied to the Great Packing Machine, esp. 62-65; Kennedy, Freedom from Fear, 747-48. 
But even as transformations in farming helped to fuel the growing desire for new industry, agribusiness continued to determine the contours of the state's industrial development program. Public officials' dogged promotion of grain alcohol factories exemplified the obeisance paid to agricultural elites. Grain alcohol plants promised not only wartime industrial jobs for Iowans but also increased demand for the state's agricultural products. Even the IIDC's own internal documents made clear that the whole campaign was due to "the efforts of agricultural interests to induce the government to build plants in Iowa for converting surplus grain to alcohol." 27

As the tide shifted in 1943 and 1944 and it became clear that the Allies would defeat Nazi Germany and the Axis powers, policymakers prepared plans to carry Iowa's industrial development program into the postwar era. After the conflict, agribusiness would once again shape industrialization in Iowa.

PUBLIC OFFICIALS, buoyed by their positive experiences with wartime industrialization, began to argue for the continuation of state industrial development initiatives during peacetime. As early as August 1942 the IIDC was in conversation with Governor Wilson about creating a Post War Planning Committee. By December 1943, the IIDC was preparing to hold a joint meeting with the recently established State Post War Rehabilitation Commission (PWRC) "with a view to coordinating the activities of the two bodies." The IIDC not only offered to share its office space and staff with the PWRC, but the IIDC's chairman, Edward Kimball, along with several other officials, also served as members of the PWRC. ${ }^{28}$

In April 1944 IIDC Secretary Selby disseminated material proposing the "organization [of] a permanent Industrial Develop-

27. Untitled report, Iowa Industrial and Defense Commission, July 15, 1942, 4, folder: 1943, box 1, Economic Development Collection: Commission Minutes and Related Materials, 1940-1954, SHSI-DM.

28. "Minutes of the Meeting of the Iowa Industrial and Defense Commission, August 13, 1942," folder: 1942, box 1, Economic Development Collection: Commission Minutes and Related Materials, 1940-1954, SHSI-DM; "Minutes of the Meeting of the Iowa Industrial and Defense Commission, December 3, 1943," folder: 1943, ibid.; "Minutes of the Meeting of the Iowa Industrial and Defense Commission, February 15, 1944," folder: 1944, ibid. 
ment Commission." At the same time, Governor Bourke Hickenlooper (who succeeded George Wilson in 1943) called on the commission to "undertake a program of industrial promotion by compiling information relative to the State's resources, opportunities and potentialities as far as raw materials, transportation, labor and other features ... for presentation to prospective industrial establishments." In December 1944 the IIDC sent Chairman Kimball and Secretary Selby to Topeka to examine the Kansas Industrial Development Commission. Apparently impressed with their findings, the IIDC appointed a committee composed of several members of the state legislature to "draft a bill for presentation to the Fifty-first General Assembly, which would provide for the creation of the Iowa Development Commission." 29 It was clear by mid- to late 1944 that Iowa was gearing up for a major industrial development drive after the war ended.

In January 1945 IIDC members discussed the recently drafted bill that proposed the creation of the Iowa Development Commission and decided to recommend its referral to the appropriate committees within the Iowa House and Senate. In March 1945 the last recorded meeting of the Iowa Industrial and Defense Commission took place. Chairman Kimball informed the group that the law to create the Iowa Development Commission had passed. At the same meeting, copies of the Iowa Development Commission's first promotional book, Iowa . . . Land of Industrial Opportunity, were passed out to each member of the soon-to-be defunct IIDC. The next time the organization released its meeting minutes, on July 13, 1945, the letterhead read "Iowa Development Commission." 30

29. "Minutes of the Meeting of the Iowa Industrial and Defense Commission, April 14, 1944," folder: 1944, box 1, Economic Development Collection: Commission Minutes and Related Materials, 1940-1954, SHSI-DM; "Minutes of the Meeting of the Iowa Industrial and Defense Commission, December 14, 1944," ibid.

30. "Minutes of the Meeting of the Iowa Industrial and Defense Commission, January 17, 1945," folder: 1945, box 1, Economic Development Collection: Commission Minutes and Related Materials, 1940-1954, SHSI-DM; "Minutes of the Meeting of the Iowa Industrial and Defense Commission, March 12, 1945," ibid.; "Minutes of the July 13, 1945 Meeting of the Iowa Development Commission," ibid. 
BY THE TIME the General Assembly approved the creation of the Iowa Development Commission in 1945, Robert D. Blue had replaced Bourke Hickenlooper as the governor of Iowa. Sworn into office in 1945, Blue oversaw the creation of the IDC and officially signed the legislation that brought the organization into existence. Archival records from Blue's administration provide insight into the motivations behind the creation of the IDC. Governor Blue's departmental files include a brief analysis of the importance of natural gas for new industry. This document offered a succinct explanation for the IDC's formation, showing that Iowa's campaign for industrial development was a direct response to the social effects of farm mechanization and rural outmigration.

Through improved farming methods and equipment, the number of people engaged in agriculture in Iowa has been less each year.... This farm population has generally moved out of the State and into more congested areas. ... For the good of the country as a whole, and for the good of Iowa in particular, it seems appropriate that every effort should be taken to develop the present industries in Iowa and secure additional ones, at least to an extent that will absorb the farm boys and girls that are not going to be needed in agriculture.

The State of Iowa, through its legislators, has created the Iowa Development Commission. Part of the duties and objects of this Commission are to aid in the industrial development of Iowa. ${ }^{31}$

The impending downward slide of agricultural employment and the population outmigration that this implied were clearly on the minds of Iowa's public officials and policymakers when the IDC was first created. In November 1945 Governor Blue commissioned Professor Ray Wakeley of Iowa State College to produce a study on population trends and their implications for the state's future. A letter from Professor William Murray, head of the Department of Agriculture and Mechanical Arts at Iowa State, to the college's president, Dr. Charles E. Friley, laid out the report's central findings: The "Iowa farm population is decreasing

31. Untitled document on natural gas for Iowa's industrial development, folder: Development and Industrial Commission, 1944-1946, Departmental and Subject Files, Records of Governor Robert D. Blue, SHSI-DM. Although the document does not have a title or date, its location in Governor Blue's records and the content of the analysis suggest that it was produced in 1945 or 1946. 
slowly," and the state needed more "business and industrial development." The report itself noted the "increased migration out of Iowa," detailing how the "farm population" had "declined .. . with increasing rapidity from 1920 to the present [1945]." 32 The existence of such a dire report on the eve of the postwar period highlighted a growing awareness that overdependence on agriculture implied the perpetual loss of young, educated citizens and a shrinking population.

While declining agricultural employment motivated public officials to extend industrial development into the postwar era, the farm economy remained interwoven with visions of Iowa's industrial future. Iowa ... Land of Industrial Opportunity, the IDC's first promotional book, captured the ongoing affiliation between agriculture and industry in the postwar period. Much like their wartime counterparts, members of the IDC argued that a massive "decentralization" of American industry was taking place. The movement of war-related industries had been motivated by defense imperatives; the relocation of private industry after the war, however, was compelled by political and economic factors. The defining feature of this industrial restructuring was manufacturing's "movement away from congested industrial centers" to "new locations" outside of urban America. A myriad of reasons were offered for industry's flight from urban areas: high taxes, unfriendly attitudes toward business, excessive costs, and overpaid and impetuous laborers. Regardless of motivations, the trend was clear: manufacturers were looking for new homes outside of their traditional urban industrial locations. ${ }^{33}$

The central goal of Iowa's industrial development campaign, according to Land of Industrial Opportunity, was to achieve a "bal-

32. William G. Murray to Dr. Charles E. Friley, 11/12/1946, folder: Changes in Iowa Population with Special Reference to Post-War Developments and State Institutions and Programs, by Ray Wakeley, box 62, Robert D. Blue Papers, Special Collections, University of Iowa Libraries, Iowa City; Ray Wakeley, "Changes in Iowa Population with Special Reference to Post-War Developments in State Institutions and Programs," 3-4, 8, ibid.

33. Iowa . . L Land of Industrial Opportunity (published by the Iowa Development Commission, Clyde Hendrix, chairman, and Rodney Selby, director), A1-A5. This book was originally published in 1945 . The version cited here (found in Iowa State University's Parks Library) does not list a publication date, but various textual clues suggest that it was an updated edition published around 1949. 
anced economy." The concept of a "balanced economy" represented an attempt to align Iowa's agricultural legacy with its industrial aspirations. According to promoters, "Iowa does not desire to become an industrial center" but rather to "increase gradually her industrial activity" so as to diversify the state's economy. In almost every sense, Iowa's campaign for industry was fashioned to avoid threatening agriculture's status. While the state welcomed any and all manufacturers interested in Iowa, and the IDC paid attention to non-farm-related industries, state promoters gave special emphasis to those firms that oriented themselves toward agriculture because, as the promotional booklet affirmed, "Obviously, the key to Iowa's industrial importance is her agriculture!" Hemp, corn, wheat, oats, pigs, chicken, milk, eggs, and other "by products from agriculture present endless opportunities for industrial development." Iowa's abundance of farm outputs would entice manufacturing and processing firms to move to the state to be "close to raw materials." In a clear nod to agribusiness interests, this model promised to increase demand for crops and other goods produced on the farm. ${ }^{34}$

While hailing the industrial potential of Iowa's agricultural abundance, promotional material also acknowledged that increases in farm productivity drove people off the land, necessitating new manufacturing employment for displaced workers. "The source of Iowa labor," the IDC explained, "is the farm." The "old fashioned" labor-intensive form of farming was "out of vogue in Iowa." Farming had become "a mechanized business" operating with scientific instruments and methods. Thus, the state had witnessed "a steady outward flow of young men and women from the farms of Iowa over the borders of the state," producing a "decrease in [farm] population of over 200,000" since 1900. But the IDC argued that workers released from agriculture would create an available pool of labor for industry. With mechanical know-how from their years working with tractors and a healthy respect for the principles of business efficiency, Iowa's farm population would serve as a stable, hard-working, and inexpensive source of labor for manufacturers. ${ }^{35}$

34. Ibid., A-4, B-1, A-9, B-13 (all italics in original).

35. Ibid., C-7, C-8, C-7-11. 
Iowa . . . the Land of Industrial Opportunity fully captured the interconnection between agriculture and industrial development. This linkage existed on multiple levels. First, increases in agricultural productivity, as a result of mechanization and government policies, created a cornucopia of farm goods that might entice food processing and manufacturing plants to the state. Seeking closer access to agricultural inputs, these firms would help to enhance Iowa's economic position by transforming farm products and raw materials into value-added consumer goods. Second, industrial development boosters clearly crafted their program to appease agribusiness interests. By focusing on farm-oriented enterprises, industrial development would not supplant agriculture but rather would benefit the farm sector by increasing demand for crops, eggs, meat, milk, and other products. Finally, and most important, the shift from labor-intensive to capitaldependent farming reduced the number of available jobs, leading Iowa's public officials to pursue new industry to keep residents from leaving the state. Without new manufacturing employment, industrial development promoters argued, the state would suffer from low incomes, population outmigration, and a shrinking tax base.

With all of these dynamics in play, Iowa . . . the Land of Industrial Opportunity offered a comprehensive roadmap for Iowa's immediate postwar economic development. Agriculture and industry would flourish side by side. Mechanization and scientific advancements would not be hindered, but championed, since greater productivity would put more money into the hands of farmers and create a surplus of agricultural goods that would attract processing firms to Iowa. There would be fewer family farms (which would not be able to compete with large landholders) and less need for farm laborers, but that would not be a problem since those displaced workers would serve as a surplus labor force for new industry. In a disturbing twist of logic, boosters viewed agrarian displacement and unemployment as a selling point for luring industrialists in search of cheap labor. IDC promotional material argued that "there is a constant surplus of the finest labor in the world in Iowa!" "The [labor] supply comes from the farms, and there is no more adaptable group in the country than 
Iowa farm boys and girls." 36 The terms "surplus" and "adaptable" implied the existence of a cheap, pliable workforce. In a harmonious and fluid process, promoters suggested, redundant farm labor would drift smoothly into newly created manufacturing jobs. Young and educated citizens, who previously had migrated to urban centers outside the state for greater opportunities, would stay in Iowa to fill these industrial positions.

During its early years of operation, the IDC promoted enterprises in harmony with farming. In 1946 the IDC published Why Iowa Is Great, a promotional book that lauded the "direct relationship between Iowa's industry and agriculture." Noting that "more than one-half of Iowa's industrial income directly depends upon agriculture," the book celebrated the state's notable "food processing and meat packing industries," naming specifically the Quaker Oats Company and Rath Packing Company. ${ }^{37}$ The Development Bulletin, the IDC's monthly news bulletin, was littered with articles focusing on farm-oriented industries, bearing headlines such as "Food Processing Top Iowa Industry" and "Industry Finds Gold in Iowa Oat Fields." 38

In March 1951 the Development Bulletin published an article profiling the Independence Canning Corporation. Located in the small town of Independence, the firm was portrayed as an archetype of postwar industrial development. The company was jointly owned by Don Forsman of the nearby town of Fredericksburg, John Van Zetten and Archie Shannon of Oskaloosa, and two Chicago businessmen. The plant was originally purchased in 1946. At that time, general manager and treasurer Darrel Forsman later recalled, "We thought we had a really good day if we turned out 1200 cans of whole chicken." By 1951 the plant was producing 9,000 cans of chicken and turkey every day. Initially, the factory had canned both poultry and corn, but it eventually gave up on

36. Ibid, A-9.

37. An excerpt from this book is published in the Iowa Development Commission's Development Bulletin, vol. 1, no. 28, November 30, 1946, 4, in folder: Development and Industrial Commission, 1944-1946, Departmental and Subject Files, Records of Governor Robert D. Blue.

38. "Food Processing Top Iowa Industry," Development Bulletin, vol. 3, no. 15, August 15, 1948, 1, in folder: Development Commission, 1947-1948, Departmental and Subject Files, Records of Governor Robert D. Blue; "Industry Finds Gold in Iowa Oat Fields," Development Bulletin, vol. 2, no. 14, August 15, 1947, 1, ibid. 
corn when the owners "realized the peak demand for poultry conflicted with the sweet corn harvest." "Under the trade name of Corn Blossom," the Development Bulletin explained, "the Independence Company puts out four sizes of whole chicken-in-thecan" that included "disjointed halves of chicken, boneless turkey and chicken, and fricassee in butter gravy." General Manager Forsman admitted that the company was forced to search as far as Tennessee, Texas, New York, and even Canada for chickens during slack periods, but he insisted that locally raised animals were their priority: "During the season, we buy all our poultry within 100 miles of Independence." A relatively small plant, with just 85 employees in 1951, the firm had nonetheless experienced substantial growth since 1947, when it had employed only 25 people. ${ }^{39}$

The Independence Canning Corporation embodied the IDC's early vision for postwar industrialization. The firm bought most of its raw materials (chickens) from poultry houses within the state, generating greater demand for local chicken farmers. Simultaneously, the firm created new jobs for residents in the local community, many of whom were no doubt being turned out of agriculture. Rather than challenging agribusiness's preeminence, the Independence Canning Corporation helped sustain large commercial farmers' quest for greater productivity, soaking up surplus raw materials while simultaneously capturing superfluous agricultural workers.

IN THE DECADES after World War II, the Iowa Development Commission could point to steady economic progress, as the number of manufacturing establishments in Iowa increased from 2,965 to 3,388 between 1947 and 1972, while the average number of production workers grew from 112,490 to 157,000. Starting in the mid- to late 1950s, agro-industrial firms would lose their privileged place in the economic development of the rural Midwest. Food products would remain one of the largest industrial sectors

39. "A Switch from Corn to Chicken Pays Off at Independence," Iowa Development Bulletin, vol. 6, no. 5, 3-4, March 15, 1951, folder 2, box 36, Departmental and Subject Files, Development Commission, Records of William S. Beardsley, SHSI-DM. There appears to have been a slight name change at some point from the original Development Bulletin to the Iowa Development Bulletin. 
throughout the twentieth century, but other manufacturing categories, such as non-electrical machinery, electrical machinery, fabricated metal, and transportation equipment, would experience substantial growth. The diversification of manufacturing throughout the rural Midwest would undermine the centrality of farm-oriented enterprises. This trend was apparent in Iowa, where, according to Wilson J. Warren, many small towns hosted "traditional agro-industrial companies as well as companies making television components, construction equipment, windows and doors, pharmaceuticals, plastics, and batteries." 40

Yet this later shift in development patterns does not negate the importance of agriculture in the IDC's early activities. Assessing Iowa's industrial progress up until 1956, the research specialist George May concluded that "the most important industries in Iowa are those which are closely linked with the farm-food processing plants and the farm equipment industry." 41 The fact remains that the emergence of state-sponsored industrial development in Iowa was inextricably linked to agriculture. The transformation of American farming inspired, justified, and legitimated the creation of a permanent development agency in Iowa. If Iowa had not been experiencing rural depopulation, outmigration, and farm modernization, it is inconceivable that the state would have invested such a significant amount of time, energy, and resources pursuing new industry.

THE CREATION of the Iowa Development Commission in 1945 marked the beginning of modern industrial development in Iowa. For the first time, the state could claim a professional, institution-

40. Warren, "Beyond the Rust Belt," 77-86 (manufacturing statistics on p. 79, quote on p. 85). Other scholars have also examined the changing composition of rural manufacturing in Iowa during the postwar period. See Rory Edward Moehnke, "The Changing Industrial Employment Structure of Iowa Communities between 1960 and 1970" (Ph.D. diss., Iowa State University, 1974); Clifford M. Baumback and Clark C. Bloom, "The Economy of Southern Iowa," Iowa Business Digest, June 1959, 22-30. I have argued elsewhere that industrial promoters and local boosters consciously shifted their focus from farm-oriented enterprises to other manufacturing sectors over the course of the postwar period. See Keith Orejel, "Factories in the Fallow: The Political Economy of America's Rural Heartland, 1945-1980" (Ph.D. diss., Columbia University, 2015).

41. May, "Recent Industrial Development" and "Iowa Industries." 
alized, and permanent industrialization program. The proximate origins of the IDC lay in the state's wartime experience. Officials and residents had worried for over 20 years that low wages and mechanization in the farm economy would drive people out of the state, but it was not until World War II that industrial development presented itself as a viable solution to those problems. The pursuit of munitions, ordnance, and grain alcohol plants gave Iowans experience in, and models for, industrial development. The Iowa Industrial and Defense Commission linked local communities and state officials with Congress, federal bureaucracies, and high-ranking politicians. Wartime industrialization provided Iowans with a sense of hope that the state could acquire manufacturing concerns. At the same time, labor shortages pushed farmers to utilize new machinery and scientific improvements, resulting in fewer available agricultural jobs after the war. In 1945 Governor Blue and the state legislature decided to meet agricultural transformations head on by creating the Iowa Development Commission. The IDC presented a plan for postwar economic development that offered industrial jobs for displaced farm workers, increased demand for agricultural products, and created a "balanced economy" for all of Iowa. The IDC's original program exemplified the inseparability of agricultural transformations and industrial development during the immediate postwar years. 